\title{
Penggunaan Media Animasi P-V Diagram Terhadap Hasil Belajar Siklus Tenaga Gas Mahasiswa Teknik Mesin
}

\author{
Yeni Ratih Pratiwi ${ }^{1}$ \\ ${ }^{1}$ Universitas Nahdlatul Ulama Blitar \\ Email: ${ }^{1}$ yeniratihpratiwi@yahoo.com
}

\begin{tabular}{l}
$\overline{\text { Tersedia Online di }}$ \\
\hline http://www.jurnal.unublitar.ac.id/ \\
index.php/briliant
\end{tabular}

Sejarah Artikel

Diterima pada 9 Maret 2018

Disetuji pada 18 Maret 2018

Dipublikasikan pada 13 Mei 2018

Hal. 139-147

\begin{tabular}{l}
\hline Kata Kunci: \\
\hline siklus tenaga gas, media animasi, \\
P-V diagram,
\end{tabular}

DOI:

http://dx.doi.org/10.28926/briliant .v3i2.160

\begin{abstract}
Abstrak: Penelitian ini bertujuan mengetahui adanya peningkatan hasil belajar pada matakuliah termodinamika melalui media animasi diagram PV pada materi siklus tenaga gas pada mahasiswa semester 3 tahun ajaran 2017/2018 di Universitas Nahdlatul Ulama Blitar. Jenis penelitian yang dilakukan adalah penelitian tindakan kelas yang dilaksanakan dalam dua siklus. Tiap siklus terdiri dari 4 tahap, yaitu tahap perencanaan, pelaksanaan tindakan, observasi, serta analisis dan refleksi. Berdasarkan hasil penelitian diperoleh rata-rata hasil perolehan nilai rata-rata prasiklus penelitian adalah 63,66 dengan tingkat ketuntasan $20 \%$. Kemudian siklus 1 nilai rata-ratanya adalah 70,7 dengan tingkat ketuntasan $53 \%$, dan pada siklus 2 nilai rata-ratanya adalah 76,5 dengan tingkat ketuntasan 90\%. Rata-rata nilai dari pra siklus, siklus I, dan siklus II menunjukkan adanya peningkatan, yang berarti ada peningkatan hasil belajar.
\end{abstract}

Pembelajaran termodinamika umumnya didominasi oleh pengenalan rumus-rumus serta konsep-konsep secara verbal, tanpa ada perhatian yang cukup terhadap pemahaman mahasiswa. Disamping itu proses belajar mengajar hampir selalu berlangsung dengan metode "chalk and talk" dosen menjadi pusat dari seluruh kegiatan di kelas. Pembelajaran termodinamika sering diiterpretasikan sebagai aktivitas utama yang dilakukan dosen, yaitu dosen mengenalkan materi, mungkin mengajukan satu atau dua pertanyaan, pembelajaran diakhiri dan selanjutnya dilakukan dengan skenario yang serupa.

Pada umumnya, sekelompok mahasiswa beranggapan bahwa mata kuliah termodinamika sulit difahami. Hal ini disebabkan oleh beberapa faktor, antara lain: Pertama, mahamahasiswa kurang memiliki pengetahuan prasyarat serta kurang mengetahui manfaat pelajaran termodinamika yang ia pelajari. Kedua, daya abstraksi mahasiswa kurang dalam memahami konsep-konsep termodinamika.

Dalam mengajarkan termodinamika, diusahakan agar mahasiswa mudah memahami konsep yang ia pelajari, sehingga mahasiswa lebih berminat untuk mempelajarinya. Jika sekiranya diperlukan media atau alat peraga yang dapat membantu mahasiswa dalam memahami konsep termodinamika, maka seyogyanya dosen menyiapkan media atau alat peraga yang diperlukan.

Mata kuliah yang diambil dalam penelitian ini adalah matakuliah termodinamika materi siklus tenaga gas. Siklus tenaga gas adalah salah satu 
materi yang harus dikuasai oleh mahamahasiswa jurusan teknik mesin di universitas. Namun pada kenyataannya dari hasil tes yang dimiliki oleh mahasiswa yang terdapat di jurnal nilai Teknik Mesin Universitas Nahdlatul Ulama Blitar tahun 2016/2017 masih belum mencapai standart ketuntasan minimal. Masih banyak nilai yang berkisar $<70$, itu artinya banyak mahasiswa yang memiliki nilai akhir termodinamika dibawah $\mathrm{B}$, bahkan ada pula yang tidak lulus. Permasalahan yang ada adalah mahasiswa kurang paham dengan teori yang diberikan karena terdapat banyak rumus maupun prinsip kerja yang harus dipahami, dan latihan soal. Sehingga mahasiswa tidak diberi kesempatan untuk berfikir dan mereka cenderung untuk menghafal. Ketika dosen menerangkan di depan kelas, mahasiswa sering merasa jenuh dengan pembelajaran termodinamika, ramai pada saat menjelaskan materi, dan mahasiswa tidak aktif.

Menurut Dienes (dalam Ruseffendi, 1990:134) menyatakan bahwa setiap konsep matematika dapat difahami dengan mudah apabila kendala utama yang menyebabkan anak sulit memahami dapat dikurangi atau dihilangkan. Dienes berkeyakinan bahwa anak pada umumnya melakukan abstraksi berdasarkan intuisi dan pengalaman kongkrit, sehingga cara mengajarkan konsep-konsep termodinamika dapat dilakukan dengan menggunakan bantuan objek kongkrit. Dengan demikian, dalam mengajarkan termodinamika perlu adanya benda-benda kongkrit yang merupakan model dari ide-ide termodinamika, yang selanjutnya disebut sebagai alat peraga sebagai alat bantu pembelajaran. Alat bantu pembelajaran ini digunakan dengan maksud agar anak dapat mengoptimalkan panca inderanya dalam proses pembelajaran, mereka dapat melihat, meraba, mendengar, dan merasakan objek yang sedang dipelajari.

Untuk mengatasi masalah di atas, perlu diadakan penelitian tindakan kelas tentang penggunaan media animasi atau alat peraga dan juga penggunaan media visual yaitu P-V diagram dalam pembelajaran materi siklus tenaga gas. Dengan serangkaian tindakan, mulai dari perencanaan, pelaksanaan, sampai dengan evaluasi, diharapkan dapat meningkatkan pemahaman mahasiswa dalam memahami materi siklus tenaga gas. Adapun rumusan masalah dalam penelitian ini adalah apakah ada peningkatan hasil belajar dalam penggunaan media animasi $\mathrm{p}-\mathrm{v}$ diagram terhadap hasil belajar siklus tenaga gas pada matakuliah termodinamika mahasiswa Teknik Mesin Universitas Nahdlatul Ulama Blitar, dan memiliki tujuan penelitian untuk dapat mengetahui peningkatan hasil belajar dalam penggunaan media animasi dan $\mathrm{p}-\mathrm{v}$ diagram terhadap hasil belajar siklus tenaga gas pada matakuliah termodinamika mahasiswa Teknik Mesin Universitas Nahdlatul Ulama Blitar.

\section{METODE}

Pendekatan yang digunakan dalam penelitian ini adalah pendekatan kuantitatif, karena penelitian ini dilaksanakan berangkat dari permasalahan pembelajaran di kelas, kemudian ditindak lanjuti dengan penerapan suatu tindakan pembelajaran kemudian direfleksi, dianalisis dan dilakukan penerapan kembali pada siklus-siklus berikutnya, setelah dilaksanakan revisi berdasarkan temuan saat refleksi.

Jenis penelitian yang digunakan adalah penelitian tindakan, yaitu peneliti berusaha untuk menerapkan suatu tindakan sebagai upaya perbaikan untuk 
mengatasi masalah yang ditemukan. Karena penelitian dilaksanakan dengan setting kelas, maka disebut penelitian tindakan kelas (Classroom Action Research)

Penelitian ini adalah penelitian tindakan kelas, model Stephen Kemmis dan Mc Taggart (dalam Suranto,200:49), model ini menggunakan sistem spiral refleksi diri yang dimulai dari rencana, tindakan, pengamatan, refleksi, dan perencanaan kembali yang merupakan dasar untuk suatu rancangan pemecahan masalah.

Prosedur penelitian diawali dengan pra tindakan yaitu mengadakan identifikasi penggunaan PV diagram pada mata kuliah termodinamika kemudian baru dilaksanakan tindakan yang terdiri dari 2 siklus. Setiap siklus tindakannya ada empat tahapan yaitu (1) persiapan/perencanaan tindakan, (2) pelaksanaan tindakan, (3) observasi dan evaluasi, dan (4) analisis dan refleksi.

Data yang dikumpulkan dalam penelitian ini berupa silabus pembelajaran, rencana pelaksanaan pembelajaran (RPP), hasil belajar mahasiswa yang dinilai dengan tes, dan hasil observasi terhadap kegiatan pembelajaran. Sumber data dalam penelitian ini adalah mahasiswa semester 3 angkatan 2016 dan dosen, serta pengamat selama berlangsungnya penilaian tindakan kelas.

Dalam penelitian tindakan kelas ini menggunakan teknik analisis data dengan memperhatikan jenis data yang dikumpulkan, yaitu analisis deskriptif. Analisis deskriptif digunakan terhadap hasil tes siklus tenaga gas menggunakan media animasi PV diagram.

Data kuantitatif dianalisis secara deskriptif antara lain dengan cara, menghitung jumlah, menghitung rata-rata, menghitung nilai persentase, dan membuat grafik. Rumus yang dipakai untuk mengetahui ketercapaian hasil belajar mahasiswa adalah sebagai berikut : (Sugiyono, 2006: 44)

Keterangan :

$$
P=\frac{f}{N} \times 100 \%
$$

$$
\begin{array}{ll}
\mathrm{P} & =\text { Persentase } \\
\mathrm{f} & =\text { frekuensi } \\
\mathrm{N} & =\text { Jumlah total mahasiswa }
\end{array}
$$

\section{HASIL}

Berdasarkan kegiatan yang telah dilaksanakan pada setiap siklus, sebanyak dua siklus dalam penelitian tindakan kelas. Tergambar pada laporan hasil penelitian yang diuraikan sebagai berikut.

Data hasil tes belajar diperoleh dari prasiklus didapatkan rata-rata nilai 63,66. Dengan kriteria penilaian :

Tabel 1. Kriteria Penilaian

\begin{tabular}{|l|l|l|l|}
\hline NILAI & ABJAD & NILAI & ABJAD \\
\hline $91-100$ & A/4 & $66-70$ & $\mathrm{C}+/ 2,5$ \\
\hline $86-90$ & $\mathrm{~A}-/ 3,70$ & $61-65$ & $\mathrm{C} / 2$ \\
\hline $81-85$ & $\mathrm{~B}+/ 3,50$ & $56-60$ & $\mathrm{C}-/ 1,70$ \\
\hline $75-80$ & $\mathrm{~B} / 3$ & $51-55$ & $\mathrm{D} / 1$ \\
\hline $71-75$ & $\mathrm{~B}-/ 2,70$ & $0-50$ & $\mathrm{E} / 0$ \\
\hline
\end{tabular}

\section{Siklus 1}




\section{Pra Tindakan}

Mahasiswa mendengarkan penjelasan tentang metode animasi, kemudian mahasiswa berdiskusi tentang penggunaan metode animasi dan langsung mempraktekkannya untuk meningkatkan hasil belajar, bahkan hal ini dikondisikan menjadi diskusi kelas. Ternyata mahasiswa tertarik dengan metode animasi diagram PV. Hal ini terlihat banyaknya mahasiswa yang bertanya dan juga memberikan tanggapan. Pertanyaan maupun tanggapan berkisar tentang pembelajaran siklus tenaga gas. Dengan temuan-temuan seperti itu merupakan jalan yang sangat baik untuk membelajarkan mahasiswa dalam rangka meningkatkan hasil belajar mahasiswa pada topik siklus tenaga gas yang akan dilaksanakan pada siklus-siklus yang direncanakan.

\section{Persiapan Tindakan}

Untuk melaksanakan tindakan sebelumnya memerlukan persiapanpersiapan yaitu: menyusun rencana pelaksanaan pembelajaran yang mengacu pada silabus yang telah dibuat dosen. Agar proses pembelajaran lancar perlu bahan ajar tentang metode animasi. Perolehan hasil penelitian dipersiapkan alat observasi baik untuk mahasiswa maupun dosen. Alat observasi berupa instrumen metode animasi, instrumen alat penilaian individu mahasiswa, instrumen observasi, instrumen observasi aktivitas dosen, dan angket mahasiswa. Peneliti dibantu observer dari dosen dan juga pengamat dari mahasiswa (Wina,2011:84).

\section{Pelaksanaan Tindakan}

Pelaksanaan tindakan pada siklus I memerlukan 2 (dua) kali tatap muka, setiap tatap muka memerlukan 2 x 50 menit dengan langkah-langkah pembelajaran sebagai berikut: (1) mahasiswa memperhatikan dosen menjelaskan materi siklus tenaga gas menggunakan PV diagram. (2) setiap mahasiswa wajib memahami semua materi yang akan diujikan secara individu pada akhir pertemuan, (3) mahasiswa bersama dosen menyimpulkan diskusi sistem pemindah tenaga sebagai acuan refleksi. (4) kegiatan akhir mahasiswa berdiskusi tentang kendala-kendala meningkatkan hasil belajar dengan menggunakan Metode animasi sebagai acuan refleksi.

\section{Observasi dan Evaluasi}

Pembelajaran siklus tenaga gas dengan media animasi dari PV diagram mahasiswa sangat antusias. Pada awal mahasiswa dengan senang memperhatikan setiap siklus pada diagram. Sejumlah 30 mahasiswa dari data aktivitas mahasiswa dalam pembelajaran siklus tenaga gas dapat diperoleh rincian tingkat pemahaman mahasiswa dalam mempresentasikan hasil kerja mereka sesuai materi yang telah dibagikan.

Berdasarkan laporan pengamat ketika mengobservasi aktivitas dosen/peneliti pada saat berlangsungnya pembelajaran, pada bagian awal terlihat bahwa dosen/peneliti sudah menjelaskan tujuan pembelajaran, dan juga telah memotivasi mahasiswa agar bisa meningkatkan hasil belajar mahasiswa. Pemodelan penggunaan media animasi untuk meningkatkan hasil belajar mahasiswa sangat kelihatan. Diskusi untuk mengetahui kendala-kendala pembelajaran media animasi dilaksanakan sebagai acuan refleksi pada siklus berikutnya. 
Dapat dijabarkan hasil penelitian tindakan kelas yaitu hasil belajar mahasiswa yang tuntas yaitu perolehan nilai 75 ke atas adalah 16 mahasiswa. Mahasiswa yang tidak tuntas atau yang hasil belajar nya kurang dari 70 adalah 14 mahasiswa. Mahasiswa yang hasil skornya tertinggi adalah dengan skor 80 dan terendah pada skor 60. Rata-rata perolehan hasil belajar mahasiswa 70,7 yang masih dalam kategori cukup $(\mathrm{C}+)$.

Pada diskusi kelompok telah terekam masalah yang dihadapi mahasiswa pada, yaitu masalah tingkat pemahaman cara kerja $80 \%$ atau 22 mahasiswa, masalah kemampuan kognitif $80 \%$ atau 22 mahasiswa, dan analisa trouble shooting $90 \%$ atau 27 mahasiswa.

\section{Analisis dan Refleksi}

Dari masalah yang dihadapi mahasiswa selama mengikuti pembelajaran dengan menggunakan media animasi PV diagram siklus tenaga gas, maka dapat direfleksikan sebagai berikut: (1) mahasiswa perlu meningkatkan pengetahuan cara kerja siklus tenaga gas pada siklus otto dengan melihat cara kerja langsung pada mobil dan teori dasar pada siklus tenaga gas, (2) mahasiswa perlu meningkatkan kemampuan kognitif dengan jalan meningkatkan daya nalar dan kepekaaan untuk mengerti dan memahami cara kerja yang terkandung dalam buku, (3) mahasiswa harus sering membaca untuk meningkatkan kepekaan tentang trouble shooting yang diberikan pada siklus tenaga gas pada siklus otto. Berdasarkan temuan hasil refleksi di atas dilakukan perbaikan untuk perencanaan siklus berikutnya.

\section{Siklus 2}

\section{Persiapan tindakan}

Berdasarkan temuan-temuan pada siklus I, siklus ke II ini merupakan bagian pemantapan pelaksanaan penelitian tindakan kelas ini. Pada persiapan tindakan, dosen/peneliti mempersiapkan rencana pelaksanaan pembelajaran (RPP), dan lembar kerja mahasiswa. Lembar observasi untuk mengetahui hasil belajar mahasiswa maupun angket untuk mahasiswa juga dipersiapkan agar penelitian tindakan kelas ini bisa maksimal.

\section{Pelaksanaan Tindakan}

Pelaksanaan tindakan pada siklus II ini merupakan siklus akhir. Dosen/peneliti menerapkan pembelajaran dengan langkah-langkah sebagai berikut: (1) Kegiatan awal mahasiswa memperhatikan dosen memberi pengarahan tentang materi yang akan diampaikan dengan media animasi, (2) Mahasiswa juga mencatat tujuan pembelajaran yang akan dicapai. (3) Mahasiswa mempresentasikan hasil yang telah dilihat di depan teman-temannya.

\section{Observasi dan Evaluasi}

Pada siklus II kendala-kendala hasil belajar telah terpecahkan baik kendala tingkat pemahaman cara kerja, kemampuan kognitif, maupun analisis trouble shooting. 
Dapat dijabarkan hasil penelitian tindakan kelas yaitu hasil belajar mahasiswa yang tuntas atau sesuai dengan Kriteria Ketuntasan Minimal yaitu perolehan nilai $75 \mathrm{ke}$ atas adalah 27 mahasiswa. Mahasiswa yang tidak tuntas atau yang hasil belajar nya kurang dari 75 adalah 3 mahasiswa. Mahasiswa yang hasil skornya tertinggi adalah dengan skor 90 dan terendah pada skor 70. Rata-rata hasil belajar pada siklus 2 adalah 75 dan pada kategori baik.

Masalah yang dihadapi mahasiswa pada siklus I telah terselesaikan dengan diperoleh data, yaitu masalah tingkat pemahaman cara kerja 30\% atau 12 mahasiswa, masalah kemampuan kognitif $40 \%$ atau 16 mahasiswa, dan analisa trouble shooting $45 \%$ atau 18 mahasiswa. Dari sini dapat dilihat bahwa frekuensi permasalahan pada mahasiswa sudah jauh menurun dibanding dengan siklus 1 .

Dari penelitian mulai dari prasiklus, siklus 1, siklus 2 maka dapat dituliskan rata rata hasil belajar prasiklus $=63,6$, hasil belajar siklus $1=70,7$, dan hasil belajar iklus $2=76,5$. Berdasarkan perolehan data dapat dilihat bahwa ada peningkatan nilai dari siklus 1 ke siklus 2, dan hasil tes evaluasi kedua terdapat 27 mahasiswa memperoleh nilai dengan kategori baik, dan 3 mahasiswa dengan kategori cukup.

\section{Analisis dan Refleksi}

Di akhir siklus ini dosen/peneliti memberikan angket kepada mahasiswa tentang pelaksanaan pembelajaran, ternyata mahasiswa menyambut positif pelaksanaan pembelajaran tersebut. Pada proses pembelajaran $90 \%$ mahasiswa menjawab ya pada point mudah diterima ketika menjelaskan metode animasi PV digram bab siklus tenaga gas untuk meningkatkan hasil belajar, 90\% menjawab ya pada point memberi kesempatan anda untuk bertanya tentang metode animasi PV diagram bab siklus tenaga gas, sebaliknya kelompok pengamat menjadi kelompok responden, $90 \%$ mahasiswa menjawab ya pada pernyataan mengkondisikan anda untuk melaksanakan penyampaian materi menggunakan media animasi PV diagram bab siklus tenaga gas untuk meningkatkan hasil belajar, 90\% mahasiswa menjawab ya pada pernyataan anda diajak berdiskusi tentang kendala-kendala saat $\mathrm{KBM}$, dan $90 \%$ mahasiswa menjawab ya pada pernyataan anda diajak berdiskusi tentang kelebihan dan kelemahan metode animasi. Pada penilaian 90\% mahasiswa menjawab ya pada pernyataan anda diberi kesempatan sebagai pengamat untuk menilai teman sendiri, dan $100 \%$ menjawab ya pada pernyataan bahwa penilaian didasarkan pada kriteria media animasi. Hasil pembelajaran 90\% mahasiswa menjawab ya pada pernyataan anda sangat senang dengan model pembelajaran metode animasi untuk meningkatkan hasil belajar, dan $90 \%$ mahasiswa menjawab ya pada pernyataan dan hasil belajar bertambah ketika menggunakan metode animasi. Hasil belajar siswa dalam siklus tenaga gas menggunakan media animasi sudah meningkat. Dengan demikian pelaksanaan pembelajaran sampai dengan siklus II mengalami keberhasilan.

\section{PEMBAHASAN}

Berdasarkan hasil penelitian, menunjukkan bahwa hasil belajar pada mata kuliah termodinamika dengan menggunakan media animasi mulai dari siklus 1 dan siklus 2 terlihat ada peningkatan dalam hasil belajar mahasiswa semester 3 Universitas Nahdlatul Ulama Blitar. Pada setiap siklus pembelajaran lebih 
difokuskan untuk meningkatkan hasil belajar mahasiswa dengan ditekankan pada tingkat pemahaman, kemampuan kognitif, dan analisa trouble shooting.

Siklus II merupakan pemantapan tindakan siklus I dalam pemahaman materi. Pada siklus 1 terlihat bahwa rata-rata hasil belajar mahasiswa adalah 70,7, sedangkan pada siklus 2 rata-rata hasil belajar mahasiswa adalah 76,5. Hal ini menunjukkan ada peningkatan persentase ketuntasan mahasiswa dalam belajar siklus tenaga gas. Pada proses pembelajaran dosen harus pandai memilih metode pembelajaran dan media pembelajaran. Pembelajaran siklus tenaga gas harus bisa menerapkan keterampilan pemahaman cara kerja, kemampuan kognitif, dan analisa trouble shooting.

Perbedaan antara kelompok mahasiswa yang diajar dengan media animasi PV diagram bab siklus tenaga gas dengan mahasiswa yang belajar melalui pembelajaran konvensional yang diamati sebelumnya menunjukkan bahwa hasil belajar dipengaruhi oleh media pembelajaran, walaupun diberi bahan pelajaran dan soal-soal tes yang setara serta memiliki fasilitas yang setara. Adanya perbedaan antara hasil belajar mahasiswa yang diajar melalui pembelajaran konvensional dengan mahasiswa yang diajar dengan media animasi PV diagram bab siklus tenaga gas dalam materi disebabkan oleh beberapa faktor, diantaranya menurut teori konstruktifistik belajar merupakan proses pembentukan pengetahuan dan pengetahuan dibentuk oleh individu yang belajar akibat adanya interaksi yang terus menerus dengan lingkungan. Belajar dapat dilihat sebagai penyusunan pengetahuan dari pengalaman kongkrit, kolaboratif, refleksi serta interpretasi. Tingkah laku yang mengalami perubahan karena belajar menyangkut berbagai aspek kepribadian baik fisik maupun psikis seperti perubahan dalam pengertian pemecahan suatu metode berfikir, keterampilan, kecakapan, kebiasaan atau sikap.

Sementara itu tujuan pembelajaran menurut teori behavioristik menekankan pada penambahan pengetahuan, sehingga dilihat sebagai aktifitas yang menuntut mahasiswa untuk mengungkapkan kembali pengetahuan yang sudah dipelajari dalam bentuk laporan kuis atau tes. Dilain pihak teori konstruktivistik menekankan tujuan pembelajaran pada mahasiswa sebagaimana belajar terutama dalam hal menciptakan pemahaman baru yang menuntut aktifitas kreatif produktif dalam konteks nyata yang mendorong mahasiswa untuk berfikir dan berfikir ulang serta mendemonstrasikan apa yang telah dipelajari. Dari hasil penelitian terungkap bahwa hasil belajar dipengaruhi oleh metode pembelajaran. Hal ini ditunjukkan oleh adanya perbedaan hasil belajar yang diperoleh melalui metode pembelajaran yang berbeda walaupun diberikan tes yang sama. Hasil belajar yang berbeda ini dise-babkan oleh perlakuan yang berbeda terhadap pebelajar yakni yang berupa penerapan metode pembelajaran yang berbeda.

Jika dihubungkan dengan media pembelajaran berarti materi pelajaran yang sama disajikan dengan media pembelajaran yang berbeda dibawah kondisi yang berbeda maka diperoleh hasil belajar yang berbeda (Arsyad, 2006:85).

Pertanyaan yang muncul adalah mengapa media animasi dapat memberikan hasil yang lebih baik dari hasil pembelajaran text book. Beberapa kemungkinan penyebabnya dapat dikemukakan sebagai berikut.

Pertama, mahasiswa terbiasa menganalisa pengetahuan baru yang ditangkap oleh media yang melibatkan minimal 2 indra (Sukirman, 2012:69). Kemudian pengetahuan yang baru didapatkan langsung didiskusikan di kelas, 
sehingga mahasiswa dituntut untuk lebih cepat memahami materi. Kedua, meningkatnya kerjasama dan keterampilan berkomunikasi sesama mahasiswa, rasa saling menghargai serta munculnya tanggung jawab personal dan kolektif. Hal ini terlihat pada saat dimana mahasiswa saling tukar pendapat maupun saling tanggap akan memberikan kritik positif terhadap pendapat teman berjalan cukup baik. Dengan adanya dukungan antar mahasiswa dan saling menghargai pendapat teman, maka mahasiswa dapat menunjukkan rasa percaya diri dan kemampuan untuk mengatasi kesulitan.

\section{KESIMPULAN}

Dari penelitian tindakan kelas yang sudah dilakukan dengan media animasi PV digram untuk mata kuliah termodinamika bab siklus tenaga gas sudah ada peningkatan hasil belajar, hal ini disebabkan oleh dua faktor diantaranya, Pertama, mahasiswa terbiasa menganalisa pengetahuan baru yang ditangkap oleh media yang melibatkan minimal 2 indra (Sukirman, 2012:69). Kemudian pengetahuan yang baru didapatkan langsung didiskusikan di kelas, sehingga mahasiswa dituntut untuk lebih cepat memahami materi. Kedua, meningkatnya kerjasama dan keterampilan berkomunikasi sesama mahasiswa, rasa saling menghargai serta munculnya tanggung jawab personal dan kolektif. Hal ini terlihat pada saat dimana mahasiswa saling tukar pendapat maupun saling tanggap akan memberikan kritik positif terhadap pendapat teman berjalan cukup baik. Dengan adanya dukungan antar mahasiswa dan saling menghargai pendapat teman, maka mahasiswa dapat menunjukkan rasa percaya diri dan kemampuan untuk mengatasi kesulitan.

\section{SARAN}

Disarankan untuk penelitian lanjutan dengan menambahkan media pembelajaran yang lain, strategi pembelajaran yang lain, metode pembelajaran yang lain, dan sebagainya. Untuk menambah jumlah anggota sampel supaya lebih dapat didapatkan data yang akurat.

\section{DAFTAR RUJUKAN}

Arsyad, A. 2006. Media Pembelajaran. Jakarta: PT. RajaGrafindo Persada.

Asyhar, R. 2012. Kreatif Mengembangkan Media Pembelajaran. Jakarta: Referensi.

Basuki. 2009. Desain Pembelajaran Berbasis Penelitian tindakan Kelas. Ponorogo : STAIN Ponorogo Press.

Daryanto. 2010. Media Pembelajaran. Yogyakarta: Gava Media.

Dinata, Y.N. 2013. Penggunaan Media Pembelajaran Animasi Tutorial untuk Meningkatkan Hasil Belajar Mahasiswa Teknik Gambar Bangunan SMK

N 1 Seyegan Pada Mata Pelajaran Menggambar dengan Autocad. Skripsi tidak diterbitkan. Yogyakarta: Universitas Negeri Yogyakarta.

Munadi, Y. 2013. Media Pembelajaran. Jakarta: Referensi

Ruseffendi, E.T. 1990. Pengajaran Matematika Modern. Bandung : Tarsito.

Sanjaya, W. 2011. Penelitian Tindakan Kelas. Jakarta : Kencana Predana Media Group.

Sugiyono. 2006. Statistika untuk Penelitian. Bandung: CV Alfabeta.

Sukirman. 2012. Pengembangan Media Pembelajaran. Yogyakarta: Pedagogia.

Suranto. 2006. Manajemen Penelitian Tindakan Kelas.Insan Cendekia. 
Uno, H.B. 2007. Teori Motivasi dan Pengukuran: Analisis di Bidang Pendidikan. Jakarta: PT Bumi Aksara.

Wiriaatmadja, R. 2006. Metode Penelitian Tindakan Kelas. Bandung : PT Remaja Rosdakarya. 